\title{
Clinical Efficacy of Valproic Acid in Relation to Plasma Levels
}

\author{
J. BRUNI, B.J. WILDER, L. J. WILLMORE, H.J. VILLARREAL, M.THOMAS, L. E. M.CRAWFORD
}

SUMMARY: Valproic acid is a new antiepileptic drug recently introduced in the United States for the treatment of absence seizures. In this study on patients with absence and other seizure types, the majority of patients achieved optimal control within four weeks of therapy. No patient responded to valproic acid who did not show an initial clinical response by

RESUMÉ: L'acide valproique est un nouveau médicament récemment lancé aux Etats Unis pour le traitement des crises d'absence. Dans la présente étude portant sur l'absence et d'autres formes de crises épileptiques, la majorité des patients ont atteint un contrôle optimal en moins de quatre semaines de traitement. Aucun patient qui n'avait répondu avant 4

From the Neurology Service, Veterans Administration Hospital: Department of Neurology. University of Florida College of Medicine, Gainesville. Florida.

This work was supported by the Medical Research Service of the Veterans Administration and the Epilepsy Research Foundation of Florida, Inc. Dr. Bruni is sponsored by the Ministry of Health. Ontario, Canada. Dr. Villarreal is sponsored by ANUIES, Mexico City, Mexico and the Epilepsy Research Foundation of Florida, Inc.

Reprint requests to: B. J. Wilder, M.D., Neurology Service (127), Veterans Administration Hospital, Gainesville. Florida 32602 U.S.A. four weeks of active therapy. Optimal response was generally achieved when plasma levels were greater than $55 \mu \mathrm{g} / \mathrm{ml}$. Excellent clinical response was observed in the treatment of absence and myoclonic seizures. Twenty-two patients continued in a long term study have maintained the same degree of seizure control as observed at the time of optimal control.

semaines ne réagit éventuellement à l'acide valproique. La réponse optimale fut généralement obtenue lorsque les taux plasmatiques dépassaient $55 \mu \mathrm{g} / \mathrm{ml}$. Une réponse clinique excellente fut observée dans le traitement des absences ou des myoclonies. Les 22 patients suivis à long terme ont maintenu les mêmes résultats qu'initialement.

\section{INTRODUCTION}

Valproic acid is a new antiepileptic drug recently licensed in the United States for the treatment of absence seizure disorders. It has been used in Europe for over ten years. Clinical studies have been conducted in this country for four years (Adams, 1978; Mattson et al., 1978; Wilder et al., 1978). Most workers (Loiseau et al., 1975; Schobben et al., 1975; Simon and Penry, 1975) have reported therapeutic plasma levels in the range of 50 to $100 \mu \mathrm{g} / \mathrm{ml}$, however, correlation with time required to achieve these levels has not been documented. We report the clinical efficacy of valproic acid in relation to plasma levels and time of onset of clinical response in relation to initiation of therapy.

The majority of patients had an initial clinical response after three weeks of valproic acid therapy. Plasma levels were greater than $55 \mu \mathrm{g} / \mathrm{ml}$. The initial clinical response corresponded to the optimal response in eleven of twenty-two patients. No patient responded to valproic acid who did not show an initial clinical response by the fourth week of therapy.

\section{MATERIALS AND METHODS}

Twenty-five patients with absence seizures were the subjects, fourteen were males and eleven were nongravid females. Ages ranged from 14 to 39 years (mean 23.9 years). The age of seizure onset ranged from 18 months to 25 years. Four patients had only absence seizures. Nineteen had a history of generalized tonic clonic seizures. Six had myoclonic seizures and eight had a history of partial seizures. Twenty-three patients with absence seizures were medically refractory and were receiving one to three antiepileptic drugs prior to the study. Two patients with absence seizures were treated only with valproic acid. One patient was dropped from analysis because of noncompliance.

The acute phase of the study lasted 16 weeks: a four week pre-entry period, a two week single blind placebo lead-in period, and ten weeks of valproic acid therapy. The starting dose ranged from 7.5 to $13.6 \mathrm{mg} / \mathrm{kg} /$ day (average $11.2 \mathrm{mg} / \mathrm{kg} /$ day) in three divided daily doses and the dosage was increased weekly depending on clinical response to a maximum of 17.9 to $62.5 \mathrm{mg} / \mathrm{kg} /$ day (average $42.7 \mathrm{mg} / \mathrm{kg}$ / day).

A seizure calendar was kept by all patients and six hour telemetered electroencephalograms were obtained at the end of the pre-entry period, after two weeks of placebo, and after 10 weeks of valproic acid therapy.

Anticonvulsant drug plasma levels were drawn at weekly intervals at similar times on each visit for eight weeks and then bi-monthly. Valproic acid assay was performed as described by Bruni et al. (1978). Other antiepileptic drugs were assayed as 
TABLE I

Response to Valproic Acid and Plasma Levels

\begin{tabular}{|c|c|c|c|c|c|}
\hline Patient & $\begin{array}{r}\text { Initia } \\
\text { Time (wks) }\end{array}$ & $\begin{array}{l}\text { I Response } \\
\text { Plasma Levels } \\
(\mu \mathrm{g} / \mathrm{ml})\end{array}$ & Time (wks) & $\begin{array}{c}\text { Optimal Response } \\
\text { Plasma Level } \\
(\mu \mathrm{g} / \mathrm{ml})\end{array}$ & $\begin{array}{c}\text { Absence Seizure } \\
\text { Reduction (\%) }\end{array}$ \\
\hline 1 & 3 & 64.6 & 3 & 64.6 & -53 \\
\hline 2 & 3 & 100.0 & 4 & 75.4 & -100 \\
\hline 3 & 3 & 55.0 & 3 & 55.0 & -100 \\
\hline 4 & - & - & - & - & +433 \\
\hline 5 & 1 & 55.4 & 4 & 62.2 & -85 \\
\hline 6 & 3 & 47.0 & 4 & 55.4 & -98 \\
\hline 7 & 3 & 63.2 & 3 & 63.2 & -70 \\
\hline 8 & 3 & 66.0 & 5 & 98.6 & -93 \\
\hline 10 & 3 & 61.8 & 3 & 61.8 & -79 \\
\hline 11 & 1 & 55.3 & 3 & 75.1 & -79 \\
\hline 12 & 3 & 78.0 & 8 & 110.0 & -100 \\
\hline 13 & 3 & 78.7 & 8 & 64.9 & -91 \\
\hline 14 & 3 & 65.6 & 3 & 65.6 & -91 \\
\hline 15 & 3 & 80.0 & 3 & 80.0 & -92 \\
\hline 16 & 2 & 84.7 & 5 & 87.5 & -100 \\
\hline 17 & 3 & 38.0 & 3 & 38.0 & -99 \\
\hline 18 & 2 & 129.0 & 3 & 136.0 & -100 \\
\hline 19 & 2 & 78.0 & 3 & 94.0 & -100 \\
\hline 20 & 3 & 60.0 & 3 & 60.0 & -100 \\
\hline 21 & 4 & 86.0 & 4 & 86.0 & -100 \\
\hline 22 & 3 & 78.4 & 3 & 78.4 & -100 \\
\hline 23 & 3 & 97.6 & 8 & 136.0 & -68 \\
\hline 24 & - & - & - & - & -24 \\
\hline 25 & 1 & 68.8 & 1 & 68.8 & -100 \\
\hline
\end{tabular}

Patient 4 - Deterioration

Patient 9 - Non-compliant

Patient 24 - No significant improvement

TABLE II

Optimal Seizure Control in Relation to Plasma Levels

Plasma Level $(\mu \mathrm{g} / \mathrm{ml})$

Number of Patients

$\begin{array}{lr}<55 & 1 \\ 55-60 & 3 \\ 61-70 & 7 \\ 71-80 & 4 \\ 81-136 & \frac{7}{22}\end{array}$

described by Perchalski et al. (1973).

Twenty-two patients were in a long term study which is still in progress.

\section{RESULTS}

Table 1 summarizes the clinical efficacy of valproic acid, its relation to plasma levels, and the time of onset of clinical response. All patients except one showed an initial response by three weeks of therapy. On the dose schedule outlined, optimal response was achieved by four weeks in 17 patients (77 per cent). Optimal response was generally achieved when plasma levels were greater than $55 \mu \mathrm{g} / \mathrm{ml}$ (2l patients); one patient achieved optimal control at $38 \mu \mathrm{g} / \mathrm{ml}$. One patient showed only mild improvement and one patient deteriorated despite therapeutic plasma levels of valproic acid. It is important to note that for optimal control some patients (7) required levels greater than $80 \mu \mathrm{g} / \mathrm{ml}$. Table 2 summarizes optimal absence seizure control in relation to plasma levels in the twentytwo patients who showed a significant response.

The response to valproic acid was best in absence and myoclonic seizures. Nineteen patients had a greater than 75 per cent absence seizure reduction. The response of other seizure types is reported in detail by Villarreal et al. (1978).

The twenty-two patients in the long term study have maintained the same degree of seizure control as observed at the time of optimal response. No patient has "escaped" from control.

\section{DISCUSSION}

In this study valproic acid was found to be highly efficient in the treatment of absence seizures. The usefulness of plasma monitoring of antiepileptic drugs has been well established (Buchtal and LennoxBuchtal, 1972; Sherwin and Robb, 1972; Penry et al., 1972; Kutt and Penry, 1974). Plasma monitoring of antiepileptic drugs helps the physician to adjust the dose individually, making allowance for differences in absorption, biotransformation, excretion, and response. In addition, it may help in determining compliance and in preventing certain dose-related side effects. The interaction between antiepileptic drugs is another phenomenon that can be studied by plasma level drug determinations.

The correlation between plasma levels of valproic acid and daily dose is only fair (R-O .349, Bruni et al., 1978; Meijer and Hessing-Brand, 1973; Schobben and Van Der Kleijin, 1974), however, a high correlation exists between clinical control and plasma levels. Twenty-one patients responded optimally with levels greater than $55 \mu \mathrm{g} / \mathrm{ml}$. Some patients require levels greater than $80 \mu \mathrm{g} / \mathrm{ml}$. Therapeutic plasma levels can be achieved within three to four weeks in the majority of patients. Optimal seizure control can be reached after four weeks in the majority of patients. Four weeks is the longest trial period necessary to determine a patient's response provided recommended plasma levels are achieved. Failure to respond by this time indicates treatment failure.

During the initiation of valproic acid therapy, interaction with other antiepileptic drugs has to be considered. In this group of patients, Wilder et al. (1978) found significant elevation of phenobarbital in eleven of thirteen patients, requiring reduction in the phenobarbital dose. Ten of fifteen patients had lower phenytoin levels, but only three required an increase in dose while on concurrent valproic acid therapy.

Plasma levels, in addition to defining a therapeutic range, also alert 
the physician to the development of possible side effects. In this group of patients, Willmore et al. (1978) found significant but transient elevation of hepatic enzymes in four patients. Enzymes returned to normal with reduction of daily dose and corresponding lower plasma levels.

In conclusion, valproic acid can help reduce the number of uncontrolled epileptics. Plasma level determinations have helped considerably in evaluating this new antiepileptic drug, however, plasma level determinations are only one aspect in the treatment of the epileptic patient and these should be used in conjunction with sound clinical judgement.

\section{ACKNOWLEDGEMENTS}

The authors wish to express appreciation to Barbara Barbour. Alfred Bauman, and Lisa Benedict for their assistance in this study. The drug was supplied by Abbott Laboratories.

\section{REFERENCES}

ADAMS, D. J., LUDERS, H., and PIPPENGER, C. (1978). Sodium valproate in the treat ment of intractable seizure disorders: A clinical and electroencephalographic study. Neurology 28:152-157.

BRUNI, J., WILDER, B. J., WILLMORE, L. J., PERCHALSKI, R. J. and VILLAR-
REAL, H. J. (1978). Kinetics of steady state valproic acid in epileptic patients. Clin. Pharmacol. Ther. (Submitted).

BUCHTAL, F. and LENNOX-BUCHTAL, M. A. (1972). Diphenylhydantoin: Relation of anticonvulsant effect to concentration in serum. In: Antiepileptic Drugs, D. M. Woodbury, J. K. Penry and R. P. Schmidt, Eds., New York: Raven Press, pp 193-209.

BUCHTAL, F. and LENNOX-BUCHTAL, $M$. A. (1972). Phenobarbital: Relation of serum concentration to control of seizures. In: Antiepileptic Drugs, D. M. Woodbury, J. K. Penry and R. P. Schmidt, Eds., New York: Raven Press, pp 335-343.

KUTT, H. and PENRY, J. K. (1974). Usefulness of blood levels of antiepileptic drugs. Arch. Neurol. 31:283-288.

LOISEAU, P., BRACHET, A. and HENRY, P. (1975). Concentration of dipropylacetate in plasma. Epilepsia 16:609-615.

MATTSON, R. H., CRAMER, J. A., WILLIAMSON, P. D. and NOVELLY, R. A. (1978). Valproic acid in epilepsy: Clinical and pharmacological effects. Ann. Neurol. 3:20-25.

MEIJER, J. W. A. and HESSING-BRAND, L. (1973). Determination of lower fatty acids, particularly the antiepileptic dipropylacetic acid, in biological material by means of micro-diffusion and gas chromatography. Clin. Chem. Acta 43:215-222.

PENRY, J. K., PORTER, R. J., and DREIFUSS, F. E. (1972). Ethosuximide: Relation of plasma levels to clinical control. In: Antiepileptic Drugs, D. M. Woodbury, J. K. Penry, and R. P. Schmidt, Eds., New York: Raven Press, pp 431-44l.
PERCHALSKI, R. J., SCOTT, K. N., WILDER, B. J., and HAMMER, R. H. (1973). Rapid simultaneous GLC determination of phenobarbital, primidone and diphenylhydantoin. J. Pharm. Sci. 62:17351736.

SCHOBBEN, F. and VAN DER KLEIJN, E. (1974). Determination of Sodium di-npropylacetate in plasma by gas-liquid chromatography. Pharm. Week. 109:30-33.

SCHOBBEN, F., VAN DER KLEIJN, E. and GABREELS, F. J. M. (1975). Pharmacokinetics of di-n-propylacetate in epileptic patients. Europ. J. Clin. Pharmacol. 8:97105.

SHERWIN, A. L., and ROBB, J. P. (1972). Ethosuximide: Relation of plasma levels to clinical control. In: Antiepileptic Drugs. D. M. Woodbury, T. K. Penry and R. P. Schmidt, Eds.. New York: Raven Press, pp 443-448.

SIMON, D., PENRY, J. K. (1975). Sodium din-propylacetate (DPA) in The Treatment of epilepsy. A review. Epilepsia 16:549-573.

VILLARREAL, H. J., WILDER, B. J., BAUMAN, A. W., HAMMOND, E. J., WILLMORE, L. J. and BRUNI, J. (1978). Effect of valproic acid on spike and wave discharge in patients with absence seizures. Neurology (In Press).

WILDER, B. J., WILLMORE, L. J., BRUNI, J. and VILLARREAL, H. J. (1978). Valproic acid: Interaction with other anticonvulsant drugs. Neurology (In Press).

WILLMORE, L. J., WILDER, B. J., BRUNI. J. and VILLARREAL, H. J. (1978). Effects of Valproic acid on hepatic function. Neurology. (Submitted). 